\title{
Peran Komunikasi Keluarga Terhadap Motivasi Belajar Anak Studi di Desa Keruak Kecamatan Keruak Kabupaten Lombok Timur Nusa Tenggara Barat
}

\author{
JAMILUDDIN1 ${ }^{1}$ \\ STIT Palapa Nusantara Lombok NTB \\ Jamilbae1@gmail.com
}

\begin{abstract}
Abstrak: Keluarga merupakan tempat pendidikan atau soialisasi pertama dan utama juga merupakan pondasi dasar bagi anak. Maka sudah sepantasnya orang tua membangun komunikasi yang baik dengan anak-anaknya, karena dengan komunikasi yang baik akan berpengaruh pada perkembangan anak secara optimal. Tujuan dari penelitian ini adalah untuk mengetahui motivasi belajar anak dan untuk mengetahui peran komunikasi keluarga terhadap motivasi belajar anak di Desa Keruak Kecamatan Keruak. Dalam penelitian ini, peneliti menggunakan purposive sampling. Adapun metode yang digunakan dalam penelitian ini adalah kualitatif dengan pendekatan deskriptif kualitatif dan teknik pengumpulan data melalui observasi, wawancara dan dokumentasi. Hasil penelitian ini menunjukan bahwa tingkat motivasi anak untuk belajar masih sangat rendah. Hal ini mengakibatkan banyak anak hanya identitasnya saja yang sekolah, tetapi anak sedikitpun tidak mendapatkan suatu ilmu. Rendahnya motivasi anak dalam belajar tersebut disebabkan karena (1) Faktor Sosial Budaya (2) Faktor Ekonomi (3) Faktor Pendidikan Orang Tua (4) Faktor Lingkungan. Sehingga untuk mengatasi permasalahan yang terjadi pada motivasi belajar anak yang rendah tersebut, sangatlah dibutuhkan peran orang tua agar bisa berkomunikasi dengan baik bersama anak-anaknya diantaranya melalui keterlibatan orang tua dalam kegiatan belajar anak di sekolah maupun di rumah dan yang terpenting yaitu penyediaan fasilitas belajar terutama bimbingan dan dorongan (motivasi).
\end{abstract}

\section{Kata kunci: Peran, Komunikasi, Keluarga, Motivasi}

${ }^{1}$ Jamiluddin STIT Palapa Nusantara Lombok NTB 


\title{
The Role of Communication Motivation Against Family Learn The Child Study In The Keruak Sub-District Keruak East Lombok Regency West Nusa Tenggara
}

\author{
JAMILUDDIN $^{2}$
}

\author{
STIT Palapa Nusantara Lombok NTB \\ Jamilbae1@gmail.com
}

\begin{abstract}
The family is home education or soialisasi first and foremost is also a basic foundation for the child. Then it is appropriate that parents build communication with her children, because with good communication will affect child development optimally. The purpose of this research is to know the child's learning and motivation to learn the role of family communication against child learning motivation in the Keruak Sub-district Keruak. In this study, researchers used a purposive sampling. As for the method used in this research is descriptive qualitative approach with qualitative and data collection techniques through observation, interview and documentation. The results of this study showed that the level of motivation of a child to learn is still very low. This has resulted in many children only credentials that school, but children do not get a science at all. Low motivation of children in the study because (1) the socio-cultural Factors (2) Factors (3) Economic factors of parent education (4) environmental factors. So to resolve problems that occur in children's learning motivation are low, it is the role of parents is required in order to be able to communicate well with her children including through the involvement of parents in the learning activities in school and in the home and crucially namely provision of learning facilities are mainly guidance and impetus (motivation).
\end{abstract}

\section{Keywords: Roles, Communication, Family, Motivation}

${ }^{2}$ Jamiluddin STIT Palapa Nusantara Lombok NTB 


\section{PENDAHULUAN}

Sumber Daya Manusia merupakan inti dan titik berat dari pembangunan nasional secara keseluruhan. Keberhasilan penetapan pembangunan nasional dimasa mendatang sangat bergantung dari kualitas manusia yang dikembangkan pada masa kini. Sumber Daya Manusia dimasa depan adalah anak-anak generasi muda pada masa kini, pada hakikatnya merupakan uapaya mengembangkan sumber daya manusia dimasa mendatang.

Garis-garis Besar Haluan Negara (GBHN) dan Undang-undang nomor 2 tahun 1989 menetapkan bahwa yang berperan atau yang bertanggung jawab terhadap pendidikan pada anak adalah keluarga, masyarakat dan pemerintah (sekolah). Ketiga unsur itu tentu mempunyai tanggung jawab bersama dalam membina anak-anak menuju kedewasaan, tetapi keberhasilan pendidikan seorang anak lebih didominasi oleh faktor orang tua atau keluarga, dalam hal ini sangat sesuai dengan pendapat Abu Ahmadi (1982 : 13) "Keluarga sebagai lembaga utama dan lembaga pertama dalam pendidikan." Hal tersebut didukung juga oleh Kartini Kartono (1985: 19) “Keluarga merupakan pendidikan yang pertama dan utama dalam kehidupan anak, tempat anak belajar dan keluarga memberi dasar, membentuk tingkah laku, watak, moral dan pendidikan anak.

Berkaitan dengan dua pendapat tersebut di atas dapat dikatakan bahwa secara genetik dan alamiah orang tualah atau keluargalah sebagai dasar untuk memberi pendidikan kepada anak dan sekaligus sebagai penanggung jawab pendidikan pada anak-anaknya. Pendidikan oleh orang tua di dalam keluarga merupakan pendidikan yang bersifat informasi dan merupakan pondasi dasar bagi pendidikan selanjutnya. Alangkah idealnya apabila orang tua dapat menjadi guru di rumah dan guru menjadi orang tua di sekolah.

Mengingat manusia sebagai makhluk sosial, manusia senantiasa ingin berhubungan dengan manusia lainnya. Ia ingin mengetahui lingkungan sekitarnya, bahkan ia ingin mengetahui apa yang terjadi didalam dirinya sendiri. Rasa ingin tahu inilah yang mendorong dan memaksa manusia untuk berkomunikasi. Menurut Dr. Everet Kleinjen ( Hafied Cangara, 2007: 1) dari East West Center Hawai, komunikasi sudah merupakan bagian kekal dari kehidupan manusia seperti halnya bernafas. Sepanjang manusia ingin hidup, ia perlu berkomunikasi. Dengan komunikasi akan 
tercipta hubungan yang harmonis, saling terbuka satu sama lain. Tetapi seperti yang kita ketahui, apabila mengingat hubungan orang tua dan anak yang sangat dekat, hendaknya sedapat mungkin dipelihara sikap saling terbuka agar tidak terjadi miscomunication antar keduanya. Menurut Harold D. Laswell (Hafied Cangara, 2007: 2) salah satu fungsi dasar menjadi penyebab mengapa manusia perlu berkomunikasi yaitu komunikasi sebagai upaya untuk melakukan transformasi warisan sosialisasi.

Sehubungan dengan uraian tersebut di atas, dapat dikatakan lagi bahwa keluarga merupakan media sosialisasi utama bagi sang anak, maka sudah sepantasnya orang tua membangun komunikasi yang lancar dengan anak-anaknya, karena dengan komunikasi yang dibina tentu dapat berperan pada perkembangan anak secara optiamal. Semakin baik komunikasi anak dengan orang tua maka semakin tinggi motivasi belajar seorang anak. Namun kadang-kadang orang tua gagal dalam membina anak maupun memotivasi anak-anak untuk meraih pendidikan yang baik, hal ini dapat disebabkan karena kurang terciptanya komunikasi yang baik, oleh karena itu sangat diperlukan bimbingan mutlak dalam bentuk komunikasi yang diperlukan. Tanggung jawab orang tua bukan hanya terbatas pada penyediaan fasilitas atau materi untuk pendidikan ank-anaknya, tetapi dorongan moril atau motivasi, sangat mendorong keberhasilan anaknya, semua inipun hanya dapat dilakukan dengan komunikasi yang baik antar keduanya. Seperti yang telah di kemukakan diatas semakin baik komunikasi orang tua dengan anak semakin tinggi pula motivasi belajar seorang anak.

Dari hal tersebut di atas dapat dilihat contoh tentang proses belajar anak yang mana dalam hal ini tentu komunikasi sangat penting untuk mendukung kelancaran belajar anak-anaknya, karena dengan komunikasi yang baik dapat membangun motivasi anak untuk belajar. Seseorang yang kurang memiliki motivasi dalam belajar tentu sulit untuk melakukan aktivitas belajar. Dengan demikian, dalam proses belajar seorang anak komunikasi yang baik dengan orang tua sangat berperan terhadap motivasi belajar anak.

Berdasarkan hasil survey yang telah dilakukan di Desa Keruak Kecamatan Keruak fakta menunjukkan bahwa banyak anak yang kurang terbuka terhadap orang tuanya, begitupun sebaliknya kebanyakan orang tua meremehkan komunikasi dengan anak khususnya menyangkut masalah pelajaran di sekolah. Dalam artian hubungan 
antara orang tua dengan anak kurang begitu erat. Dari hal inilah penulis ingin lebih mendalami tentang bagaimanakah sebenarnya peran komunikasi orang tua dalam memotivasi anak agar mereka menjadi anak yang semangat serta giat dalam belajar. Oleh karena itu diangkatlah judul "Peran Komunikasi Keluarga Terhadap Motivasi Belajar Anak Di Desa Keruak Kecamatan Keruak.”

\section{Kajian Pustaka}

\section{A. Komunikasi}

1. Pengertian Komunikasi

Komunikasi adalah suatu transaksi, proses simbolik yang menghendaki orang-orang mengatur lingkungannya dengan 1) membangun hubungan antar manusia, 2) melalui penukaran informasi, 3) menguatkan sikap dan tingkah laku orang lain serta 4) berusaha mengubah sikap dan tingkah laku itu (Hafied Cangara 2007:20)

2. Bentuk-bentuk Komunikasi

Bentuk-bentuk komunikasi (dalam Karti Suharto, 2003:12) antara lain:

a. Komunikasi personal yang terdiri dari komunikasi intra personal dan komunikasi antar personal.

b. Komunikasi kelompok yang terdiri dari kelompok kecil dan kelompok besar.

c. Komunikasi tatap muka dan komunikasi bermedia.

d. Komunikasi verbal (lisan maupun tulisan) dan non verbal gerakan tubuh/isyarat dan bergambar.

3. Tujuan komunikasi

Menurut Arnold dan Bowers, 1984; Naisbit.1984 tujuan komunkasi adalah

a. Menemukan

b. Salah satu tujuan utama komunikasi menyangkut penemuan diri (personal discovery)

. Dengan berbicara tentang diri kita sendiri dengan orang lain kita memperoleh umpan balik yang berharga mengenai perasaan, pemikiran, dan perilaku kita. Dari perjumpaan seperti ini kita menyadari, misalnya bahwa perasaan kita ternyata tidak jauh berbeda dengan perasaan orang lain. Pengukuhan positif ini membantu kita merasa "normal."

c. Untuk Berhubungan 
Salah satu motivasi kita yang paling kuat adalah berhubungan dengan orang lain (membina dan memelihara hubungan dengan orang lain). Kita ingin merasa dicintai dan disukai, dan kemudian kita juga ingin mencintai dan menyukai orang lain. Kita menghabiskan banyak waktu dan energi komunikasi kita untuk membina dan memelihara hubungan sosial.

d. Untuk Meyakinkan

Media masa ada sebagian besar untuk meyakinkan kita agar mengubah sikap dan perilaku kita. Media dapat hidup karena adanya dana dari iklan, yang diarahkan untuk mendorong kita membeli berbagai produk.

e. Untuk Bermain

Kita menggunakan banyak perilaku komunikasi kita untuk bermain dan menghibur diri. Kita mendengarkan pelawak, pembicaraan, musik, dan film sebagian besar untuk hiburan. Demikian pula banyak dari perilaku komunikasi kita dirancang untuk menghibur orang lain (menceritakan lelucon mengutarakan sesuatu yang baru, dan mengaitkan cerita-cerita yang menarik). Adakalanya hiburan ini merupakan tujuan akhir, tetapi adakalanya ini merupakan cara untuk mengikat perhatian orang Iain sehingga kita dapat mencapai tujuan-tujuan lain.

4. Jenis Komunikasi

Jenis komunikasi terdiri dari:

a. Komunikasi Verbal mencakup aspek-aspek berupa ;

i. Vocabulary (perbendaharaan kata-kata). Komunikasi tidak akan efektif bila pesan disampaikan dengan kata-kata yang tidak dimengerti, karena itu olah kata menjadi penting dalam berkomunikasi.

ii. Racing (kecepatan). Komunikasi akan lebih efektif dan sukses bila kecepatan bicara dapat diatur dengan baik, tidak terlalu cepat atau terlalu lambat.

iii. Intonasi suara: akan mempengaruhi arti pesan secara dramatik sehingga pesan akan menjadi lain artinya bila diucapkan dengan intonasi suara yang berbeda. Intonasi suara yang tidak proposional merupakan hambatan dalam berkomunikasi.

iv. Humor: dapat meningkatkan kehidupan yang bahagia. Dugan (1989), memberikan catatan bahwa dengan tertawa dapat membantu menghilangkan 
stress dan nyeri. Tertawa mempunyai hubungan fisik dan psikis dan harus diingat bahwa humor adalah merupakan satu-satunya selingan dalam berkomunikasi.

v. Singkat dan jelas. Komunikasi akan efektif bila disampaikan secara singkat dan jelas, langsung pada pokok permasalahannya sehingga lebih mudah dimengerti.

vi. Timing (waktu yang tepat) adalah hal kritis yang perlu diperhatikan karena berkomunikasi akan berarti bila seseorang bersedia untuk berkomunikasi, artinya dapat menyediakan waktu untuk mendengar atau memperhatikan apa yang disampaikan.

b. Komunikasi Non Verbal

Komunikasi non verbal adalah penyampaian pesan tanpa kata-kata dan komunikasi non verbal memberikan arti pada komunikasi verbal. Yang termasuk komunikasi non verbal adalah :

i. Ekspresi wajah, wajah merupakan sumber yang kaya dengan komunikasi, karena ekspresi wajah cerminan suasana emosi seseorang.

ii. Kontak mata, merupakan sinyal alamiah untuk berkomunikasi. Dengan mengadakan kontak mata selama berinterakasi atau tanya jawab berarti orang tersebut terlibat dan menghargai lawan bicaranya dengan kemauan untuk memperhatikan bukan sekedar mendengarkan. Melalui kontak mata juga memberikan kesempatan pada orang lain untuk mengobservasi yang lainnya

iii. Sentuhan adalah bentuk komunikasi personal mengingat sentuhan lebih bersifat spontan dari pada komunikasi verbal. Beberapa pesan seperti perhatian yang sungguh-sungguh, dukungan emosional, kasih sayang atau simpati dapat dilakukan melalui sentuhan.

iv. Postur tubuh dan gaya berjalan. Cara seseorang berjalan, duduk, berdiri dan bergerak memperlihatkan ekspresi dirinya. Postur tubuh dan gaya berjalan merefleksikan emosi, konsep diri, dan tingkat kesehatannya.

v. Sound (Suara). Rintihan, menarik nafas panjang, tangisan juga salah satu ungkapan perasaan dan pikiran seseorang yang dapat dijadikan komunikasi. 
Bila dikombinasikan dengan semua bentuk komunikasi non verbal lainnya sampai desis atau suara dapat menjadi pesan yang sangat jelas.

vi. Gerak isyarat, adalah yang dapat mempertegas pembicaraan . Menggunakan isyarat sebagai bagian total dari komunikasi seperti mengetuk-ngetukan kaki atau mengerakkan tangan selama berbicara menunjukkan seseorang dalam keadaan stress bingung atau sebagai upaya untuk menghilangkan stress.

\section{B. Motivasi belajar}

1. Pengertian Motivasi

Kata motivasi berasal dari kata "motif' yang berarti alasan melakukan sesuatu, sebuah kekuatan yang menyebabkan seseorang bergerak melakukan suatu kegiatan. Dalam Kamus Besar Bahasa Indonesia, (Depdikbud, 1996: 593) motivasi didefinisikan sebagai dorongan yang timbul pada diri seseorang sadar atau tidak sadar untuk melakukan sesuatu tindakan dengan tujuan tertentu.

Sondang P. Siagian

2004:138) memberikan definisi motivasi sebagai daya dorong yang mengakibatkan seseorang mau dan rela untuk mengerahkan kemamppuan, tenaga dan waktunya dalam rangka pencapaian tujuan yang telah ditentukan sebelumnya.

Sedangkan pendapatnya Sardiman (1994: 73) mengemukakan Motif adalah daya upaya yang mendorong seseorang untuk melakukan sesuatu. Motif dapat dikatakan sebagai daya penggerak dari dalam diri dan di dalam subyek untuk melakukan aktifitas-aktifitas tertentu demi mencapai suatu tujuan. Motif dapat juga diartikan sebagai suatu kondisi intern (kesiapsiagaan). Sedangkan motivasi diartikan sebagai daya penggerak yang telah menjadi aktif. Motivasi dapat juga diartikan sebagai serangkaian usaha untuk menyediakan kondisi-kondisi tertentu sehingga seseorang mau dan ingin melakukan sesuatu.

Dari beberapa definisi di atas dapat disimpulkan bahwa motif dapat diartikan sebagai daya upaya yang mendorong seseorang melakukan sesuatu. sedangkan motivasi adalah dorongan atau kekuatan dalam diri individu untuk melakukan sesuatu dalam mencapai suatu tujuan.

2. Jenis Motivasi

a. Motivasi primer, adalah motivasi yang didasarkan pada motif-motif dasar.

Motif-motif dasar tersebut umumnya berasal dari segi biologis atau jasmani 
manusia. Manusia adalah makhluk berjasmani, sehingga prilakunya terperan oleh insting atau kebutuhan jasmaninya. Diantara insting-insting yang penting adalah memelihara, mencari makan, melarikan diri, berkelompok, mempertahankan diri, rasa ingin tahu, membangun dan kawin (Jalalludin Rahhmat, 1991: 34).

b. Motivasi skunder adalah motivasi yang dipelajari atau disebut juga motivasi sosial. Karl Mark (dalam Jalalludin Rahmat, (1991: 34)

3. Sifat Motivasi

Motivasi seseorang dapat bersumber dari : 1) dalam diri sendiri yang dikenal sebagai motivasi intrinsik, dan 2) dari luar dan seseorang yang dikenal sebagai motivasi ekstrinsik.

Motivasi intrinsik dan ekstrinsik dapat dijadikan titik pangkal rekayasa pendagogis guru, sebaiknya guru mengenal adanya motivasi-motivasi tersebut.

4. Pengertian Motivasi Belajar

Motivasi dalam kegiatan belajar menurut Winkel WS (2009: 39) Motivasi belajar adalah keseluruhan daya penggerak di dalam diri siswa untuk menimbulkan kegiatan belajar dan memberikan arah pada kegiatan belajar itu, maka tujuan yang dikehendaki siswa tercapai."

Bila diterapkan dalam konteks belajar, motivasi belajar didefinisikan sebagai suatu konsep untuk menjelaskan tentang daya (process) yang dimiliki oleh subyek didik yang berperan mengarahkan prilaku belajar.

5. Fungsi Motivasi Dalam Belajar

Sebagaimana yang dinyatakan oleh Hamalik bahwa fungsi motivasi secara umum sebagai berikut :

a. Mendorong timbulnya kelakuan atau suatu perbuatan, tanpa motivasi tidak akan timbul perbuatan

b. Sebagai pengarah, artinya mengarahkan perbuatan kepada pencapaian tujuan yang diinginkan

c. Sebagai penggerak, artinya menggerakkan tingkah laku seseorang kuat lemahnya motivasi akan menentukan cepat atau lambatnya suatu pekerjaan. 


\section{METODE PENELITIAN}

Penelititan ini merupakan penelitian kualitatif, penelitian kualitatif menekankan pada kejadian/ fonemena, gejala sosial yang ingin diungkap maknanya. Penelitian kualitatif dapat didesain untuk memberikan sumbangannya terhadap teori, praktisi, kebijakan, masalah sosial dan tindakan. Penelitian ini dilakukan di Daerah Lombok Timur khususnya di Desa Keruak Kecamatan Keruak Provinsi Nusa Tenggara Barat dengan menggunakan pendekatan deskriptif kualitatif.

Penelitian ini mengkaji tentang Peran Komunikasi Keluarga Terhadap Motivasi Belajar Anak di Desa Keruak Kecamatan Keruak. Dalam sebuah penelitian dikenal dengan jenis dan sumber data primer dan sumber sekunder. sedangkan teknik pengumpulan data yang digunakan dalam penelitian ini, antara lain Observasi, wawancara dan Dokumentasi.

Setelah data yang diperlukan terkumpul, kemudian data tersebut dianalisis dengan cara:

a. Reduksi data (Data Reduction) melakukan analisis data dengan cara merumuskan, memilih hal-hal pokok, menfokuskan pada hal-hal penting, dan membuat katagori sehingga memberikan gambaran agar jelas serta mempermudah peneliti dalam menganalisis data.

b. Penyajian data (Display Data) mengorganisasikan data, membuat kedalam pola, membuat uraian singkat bagan, hubungan antar kategori, langkah-langkah yang dilakukan adalah; (1). data yang telah diseleksi diinternalisasikan dan direlevansikan dengan data etik, (2). informasi yang diperoleh dari wawancara diinterprestasikan untuk memberikan gambaran mendeskrifsikan fokus-fokus masalah.

c. Conclusion Drawing/ Verivication. Penarikan kesimpulan setelah menyajikan data peneliti akan menarik sebuah kesimpulan untuk menjawab rumusan masalah dan memberikan saran-saran berdasarkan hasil penelitian dan kesimpulam yang diambil. 


\section{HASIL DAN PEMBAHASAN}

\section{A. Tingkat Motivasi Belajar Anak Di Desa Keruak Kecamatan Keruak}

Keluarga adalah kelompok terkecil berupa pengelompokan primer yang terdiri atas sejumlah kecil orang karena hubungan sedarah dan sekerabat. Peran dan fungsi keluarga dalam proses pendidikan anak sangat fundamental. Pendidikan keluarga bagi anak merupakan pendidikan pertama dan utama sehingga warnanya sangat sulit di hilangkan dari dalam diri anak. Keluarga inilah yang menjadi dasar pendidikan anak baik di sekolah maupun di masyarakat. Keluargalah yang mengajarkan dan yang menanamkan keyakinan keagamaan pada anak, nilai budaya, adat istiadat, nilai moral, tata krama, dan berbagai keterampilan untuk dapat bertahan hidup, seperti merangkak berjalan, berlari, mengembangkan ide, pemikiran dan lainlain. Tetapi peneliti menemukan hal yang tidak seharusnya terjadi yaitu tingkat motivasi anak untuk belajar sangat rendah.

Hal ini mengakibatkan banyak anak hanya identitasnya saja yang sekolah, tetapi anak sedikitpun tidak mendapatkan suatu ilmu. Berdasarkan hasil wawancara peneliti dari tokoh masyarakat yaitu Bapak Ruslan S. Pd bahwa:

Apabila kita melihat dari tingkat motivasi anak di Desa ini dapat di katakana tingkat motivasi anak untuk belajar masih terbilang rendah, dimana sebagian dari anak-anak di Desa Keruak banyak yang tidak tamat SMP/SMA. Hal ini di sebabkan karna anak kurang mendapatkan motivasi dari orang tua mereka (wawancara, tgl 14 Oktober 2015 ).

Hal senada juga dikatakan oleh Seorang tokoh agama yang bernama H. Juaini haramain mengatakan bahwa :

Pendidikan anak pada hakikatnya adalah tanggung jawab para orang tua. Oleh karena itu, keterlibatan orang tua dalam mendukung sukses anak menuntut ilmu di sekolah merupakan kewajiban. Untuk menjadi pendidik yang baik, orang tua mesti menghiasi dirinya dengan berbagai hal seperti kesadaran akan pentingnya beribadah, akhlak yang baik, dan kesadaran akan tanggung jawabnya sebagai orang tua dan mendorong keberhasilan anak-anaknya dalam 
berbagai hal (kesarana sosial) terutama dalam hal motivasi ( Wawancara, Tanggal 15 Oktober 2015).

Terkait dengan keluarga dalam memotivasi seorang anak untuk belajar khususnya di Desa Keruak seperti yang di kemukakan di atas masih tergolong rendah. Hal ini disebabkan kurangnya kesadaran masyarakat (orang tua) akan arti pentingnya dorongan/motivasi kepada anak-anaknya untuk belajar.

Berdasarkan hasil penelitian di lapangan, penulis menemukan indikator yang merupakan penyebab kurangnya perhatian orang tua dalam hal memberikan motivasi anak-anaknya untuk belajar di Desa Keruak, diantaranya:

1. Faktor Sosial Budaya

2. Faktor Ekonomi

3. Faktor Geografis

4. Faktor Pendidikan Orang Tua

5. Faktor Lingkungan

B. Peran Komunikasi Keluarga Terhadap Motivasi Belajar Anak Di Desa Keruak Kecamatan Keruak

Melihat kenyataan di lapangan peran serta orang tua sangat dibutuhkan oleh setiap anak terutama dalam bidang pendidikan maupun dalam pembentukan kepribadian anak. Kesadaran penuh orang tua terhadap tanggung jawabnya dalam mendidik anak merupakan kondisi dasar untuk memulai keberhasilan khususnya peranan komunikasi orang tua dalam memberikan dorongan atau motivasi terhadap anak.

Bentuk-bentuk komunikasi orang tua dalam meningkatkan motivasi belajar anak adalah: 1) orang tua menanyakan apa saja keluhan seorang anak dalam proses belajar yang sedang ia lakukan, 2) orang tua menanyakan keadaan anak setiap waktu, 3) orang tua selalu memberikan nasehat secara baik-baik setiap anak melakukan kesalahan.

Oleh Ki Hajar Dewantara mengatakan bahwa "orang tua (sebagai pendidik) mengabdi kepada sang anak". Motivasi pengabdian keluarga (orang tua) ini sematamata demi cinta kasih yang kodrati. Di dalam suasana cinta dan kemesraan ini proses pendidikan berangsur seumur anak itu dalam tanggung jawab keluarga. 
Mencermati kalimat diatas terdapat beberapa bentuk peran orang tua meliputi:

a) Kesadaran orang tua akan kemajuan pendidik

b) Keterlibatan orang tua dalam kegiatan belajar anak di sekolah maupun di rumah.

c) Penyediaan fasilitas belajar anak terutama bimbingan dan dorongan.

d) Menjalin Hubungan komunikasi yang baik antara orang tua dan anak.

Adapun hal yang harus dipersiapkan oleh orang tua untuk mewujudkan keluarga dalam tataran konsep keluarga yang harmonis dalam hal komunikasi yang akhirnya membuat anak menjadi termotivasi untuk belajar di Desa Kenrak Kec Kenrak, diantaranya:

1. Keteladanan

2. Keperdulian

3. Meningkatkan SDM

\section{BAB V \\ KESIMPULAN DAN SARAN}

\section{A. Kesimpulan}

Berdasarkan apa yang telah dideskripsikan sebelumnya, maka dalam hal ini dapat disimpulkan bahwa:

1. Tingkat motivasi anak untuk belajar masih terbilang rendah. Hal ini turut dipengaruhi oleh faktor ekonomi, budaya, geografis dan rendahnya pendidikan orang tua.

2. Peran komunikasi orang tua dalam memotivasi anak untuk belajar masih terbilang minim sekali hal ini dapat di simpulkan dari hasil wawancara peneliti kepada warga masyarakat tersebut, tetapi ini dapat di tangani oleh beberapa aspek yaitu mulai dari kesadaran orang tua akan kemajuan pendidikan, keterlibatan orang tua dalam kegiatan belajar anak di sekolah maupun di rumah dan yang terpenting yaitu penyediaan fasilitas belajar terutama bimbingan dan dorongan (motivasi).

\section{B. Saran-Saran}

Berdasarkan hasil penelitian dan pembahasan dapat diajukan beberapa saran kepada semua pihak yang terkait dalam usaha keberhasilan pendidikan anak 
khususnya dalam meningkatkan peran komunikasi orang tua dalam memotivasi anak untuk belajar di Desa Keruak:

1. Perlu adanya kesadaran dari orang tua serta adanya persamaan persepsi tentang pentingnya peran pendidikan untuk mendapatkan kehidupan yang lebih baik.

2. Orang tua seharusnya membangun komunikasi yang efektif dalam keluarga sehingga tidak tercipta kecanggungan dalam berkomunikasi terutama oleh anak.

3. Diharapkan adanya optimalisasi proses belajar dalam lingkungan keluarga sehingga akan melahirkan pribadi unggul secara intelektual, spiritual, maupun emosional. Karena keluarga meskipun sebagai organisasi terkecil dalam masyarakat namun sangat besar pengaruhnya terhadap pengembangan tiga potensi tersebut.

4. Pemerintah yang sebagai motivator, fasilitator dalam dunia pendidikan, harus mampu mendorong dan menyadarkan masyarakat bagaimana pentingnya pendidikan, melalui proses sosialisasi.

\section{DAFTAR PUSTAKA}

Ahmadi, Abu. 1982. Sosiologi Pendidikan: membahas Gejala Pendidikan Dalam Konteks Struktur Sosial Masyarakat. Jakarta: Bina Ilmu.

Arnold dan Bowers, 1984; Naisbit.1984

A.M, Sardiman, 1994, interaksi dan motivasi Belajar Mengajar. Jakarta: Gravindo Persada. Cangara, Hafied. 2007. Pengantar Ilmu Komunikasi. Jakarta: PT. Raja Grafindo Persada

Depdikbud, 1996. Kamus Besar Bahasa Indonesia, Jakarta: Balai Pustaka.

Kartini, Kartono. 2005. Patologi Sosial 2; Kenakalan Remaja. Jakarta: Rajawali Pers

Karti Soeharto, dkk. 2003. Tehnologi Pembelajaran (Pendekatan Sistem, Konsepsi dan Model, SAP, Evaluasi, Sumber Belajar Media) Surabaya: surabaya internasional Club.

Omar Hamalik, 2001. Proses Belajar Mengajar. Jakarta: PT. Bumi Aksara.

Rahmat, Jallaluddin. 1991. Metode Penelitian Komunikasi. Bandung: Remaja Rosda Karya.

Sondang P. Siagian, 2004. Teori Motivasi dan Aplikasinya. Jakarta: PT. Rineka Cipta.

Winkel, WS. 2009. Psikologi Pengajaran. Yogyakarta: Media Abadi. 